\title{
PUSHOVER ANALYSIS OF MULTY STORY BUILDING
}

\author{
D.N. Shinde ${ }^{1}$, Nair Veena $V^{2}$, Pudale Yojana $M^{3}$ \\ ${ }^{1}$ Associate Professor, Department of Civil Engineering, P.V.P.I.T. Budhgaon, Maharashtra, India \\ ${ }^{2}$ Student, Department of Civil Engineering, P.V.P.I.T. Budhgaon, Maharashtra, India \\ ${ }^{3}$ Student, Department of Civil Engineering, P.V.P.I.T. Budhgaon, Maharashtra, India
}

\begin{abstract}
Pushover analysis is a static, nonlinear procedure using simplified nonlinear technique to estimate seismic structural deformations. It is an incremental static analysis used to determine the force-displacement relationship, or the capacity curve, for a structure or structural element. The analysis involves applying horizontal loads, in a prescribed pattern, to the structure incrementally, i.e. pushing the structure and plotting the total applied shear force and associated lateral displacement at each increment, until the structure or collapse condition. In technique a computer model of the building is subjected to a lateral load of a certain shape (i.e., inverted triangular or uniform). The intensity of the lateral load is slowly increased and the sequence of cracks, yielding, plastic hinge formation, and failure of various structural components is recorded. Pushover analysis can provide a significant insight into the weak links in seismic performance of a structure. The performance criteria for pushover analysis are generally established as the desired state of the building given roof-top or spectral displacement amplitude.
\end{abstract}

The seismic response of $R C$ building frame in terms of performance point and the effect of earthquake forces on multi story building frame with the help of pushover analysis is carried out in this paper. In the present study a building frame is designed as per Indian standard i.e. IS 456:2000 and IS 1893:2002. The main objective of this study is to check the kind of performance a building can give when designed as per Indian Standards. The pushover analysis of the building frame is carried out by using structural analysis and design software SAP 2000.

Keywords: Pushover Analysis, Non linear Static analysis, Performance point, Capacity curve

\section{INTRODUCTION}

Pushover analysis is an approximate analysis method in which the structure is subjected to monotonically increasing lateral forces with an invariant height-wise distribution until a target displacement is reached. Pushover analysis consists of a series of sequential elastic analysis, superimposed to approximate a force-displacement curve of the overall structure. A two or three dimensional model which includes bilinear or trilinear load-deformation diagrams of all lateral force resisting elements is first created and gravity loads are applied initially. A predefined lateral load pattern which is distributed along the building height is then applied. The lateral forces are increased until some members yield. The structural model is modified to account for the reduced stiffness of yielded members and lateral forces are again increased until additional members yield. The process is continued until a control displacement at the top of building reaches a certain level of deformation or structure becomes unstable. The roof displacement is plotted with base shear to get the global capacity curve.

Pushover analysis can be performed as force-controlled or displacement-controlled. In force- controlled pushover procedure, full load combination is applied as specified, that is, force- controlled procedure should be used when the load is known. Also, in force-controlled pushover procedure some numerical .Problems that affect the accuracy of results occur since target displacement may be associated with a very small positive or even a negative lateral stiffness because of the development of mechanisms and P-delta effects.

Pushover analysis is the preferred tool for seismic performance evaluation of structures by the major rehabilitation guidelines and codes because it is conceptually and computationally simple. Pushover analysis allows tracing the sequence of yielding and failure on member and structural level as well as the progress of overall capacity curve of the structure as per Girgin. et., 2007.[1]

\section{CASE STTUDY DETAILS:}

For obtaining performance point a building frame of $\mathrm{G}+10$ floors is considered. It is consisting of two bays in both the directions. The spacing along $\mathrm{X}$ and $\mathrm{Y}$ directions is $5 \mathrm{~m}$ and the story height is taken as $3 \mathrm{~m}$. The frame is located in seismic zone III.

\subsection{Design Data:}

- $\quad$ Live load : $4.0 \mathrm{kN} / \mathrm{m} 2$ at typical floor : $1.5 \mathrm{kN} / \mathrm{m} 2$ on terrace 
- Floor finish $\quad: 1.0 \mathrm{kN} / \mathrm{m} 2$

- Water proofing : $2.0 \mathrm{kN} / \mathrm{m} 2$

- Earthquake load : As per IS-1893 (Part 1)2002

- Storey height : $3 \mathrm{~m}$

- Floors : G.F + 10 upper floors.

- Plinth level : $0.6 \mathrm{~m}$

- Walls : $230 \mathrm{~mm}$ thick brick masonry walls Only at periphery

- Seismic zone : Zone III

\subsection{Description of Building Frame:}

- No. Bays along $X$ axis : 2

- No. Of bays along Y axis : 2

- Spacing along $X$ axis : $5 \mathrm{~m}$

- $\quad$ Spacing along Y axis : $5 \mathrm{~m}$

- Story height: $4 \mathrm{~m}$

- No. Of floors: G + 10

- Size of column : $500 \times 500 \mathrm{~mm}$

- Size of beam : $300 \times 600 \mathrm{~mm}$

- Slab : $150 \mathrm{~mm}$ thick

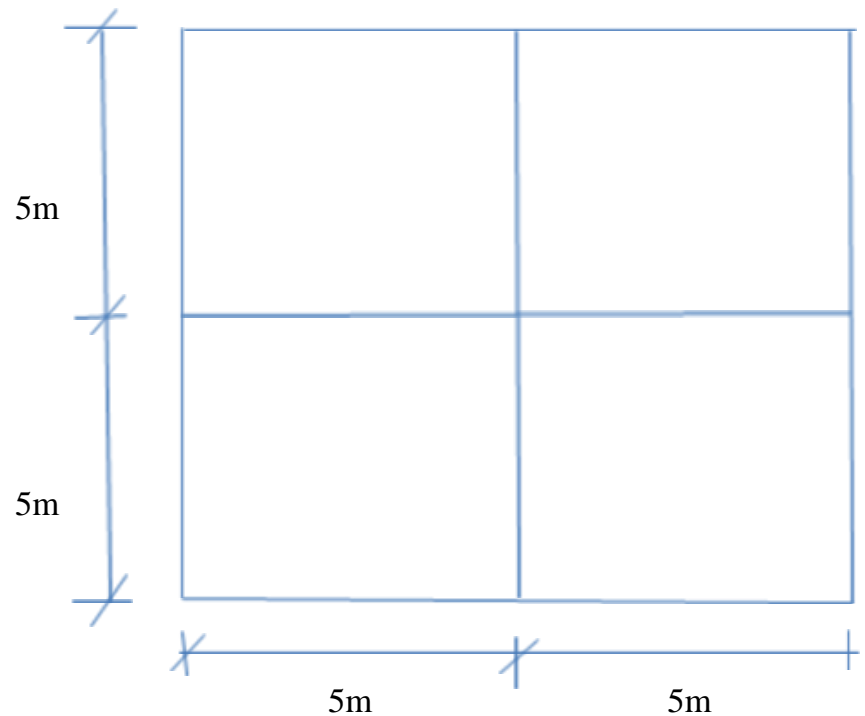

Fig-1: Plan of building frame

\section{CALCULATION OF DESIGN BASE SHEAR}

For obtaining the performance point of the building frame in terms of base shear the design base shear is calculated for determining the safety of the frame. The intersection of demand spectrum and capacity spectrum is the performance point of the structure. If the base shear at performance point is greater than design base shear then the structure is safer. The design base shear is calculated as per IS : 1893:2002 [6] as follows:

The seismic weight of building is found to be $32677 \mathrm{KN}$ (Wi) The infill walls in upper floors may contain large openings, although the solid walls are considered in load calculations. Therefore, fundamental time period $\mathrm{T}$ is obtained by using the following formula

$$
\begin{gathered}
\mathrm{T}_{\mathrm{a}}=0.075 \mathrm{~h}^{0.75} \underline{\text { IS } 1893(\text { Part 1):2002, Clause 7.6.1 }} \\
\mathrm{T}_{\mathrm{a}}=0.075 \times(30)^{0.75} \\
\mathrm{~T}_{\mathrm{a}}=0.96 \mathrm{sec} .
\end{gathered}
$$

Zone factor, $Z=0.16$ for Zone III IS: 1893 (Part1):2002, Table 2

Importance factor, $I=1.0$, Medium soil site and 5\% damping

$$
\mathrm{Sa} / \mathrm{g}=1.36 / 0.97=1.42 \text { IS: } 1893 \text { (Part 1): 2002, Figure } 2 .
$$

Ductile detailing is assumed for the structure. Hence, Response Reduction Factor, $R$, is taken equal to 5.0. It may be noted however, that ductile detailing is mandatory in Zones III, IV and V. Hence, horizontal seismic coefficient is calculated as

$$
\begin{aligned}
\mathrm{A}_{\mathrm{h}}=(\mathrm{Z} / 2) \times(\mathrm{I} / \mathrm{R}) \times\left(\mathrm{S}_{\mathrm{a}} / \mathrm{g}\right) \underline{\text { IS: } 1893(\text { Part } 1): \text { 2002, clause } 6.4 .2} \\
\mathrm{~A}_{\mathrm{h}}=(0.16 / 2) \times(1.0 / 5) \times 1.42=0.022
\end{aligned}
$$

The design Base shear, $V \mathrm{~B}=A \mathrm{~h} \times W_{\text {IS: }} 1893$ (Part 1): $\underline{2002, \text { clause 7.7.1 }}$

$$
V \mathrm{~B}=0.022 \times 32677=720 \mathrm{KN}
$$

\section{RESULTS}

On the above building frame the non linear static pushover analysis is performed to investigate the performance point of the building frame in terms of base shear and displacement. For pushover analysis the various pushover cases are considered such as push gravity, push X (i.e. loads are applied in $\mathrm{X}$ direction), push $\mathrm{Y}$ (i.e. loads are applied in $\mathrm{Y}$ direction). The various load combinations are also used for this purpose. After pushover analysis the demand curve and capacity curves are obtained to get the performance point of the structure. The performance point is obtained as per ATC 40 capacity spectrum method. The base shear for PUSH X load case is (904.612 KN). And for PUSH Y base shear at performance point is (915.197) as shown in figure 


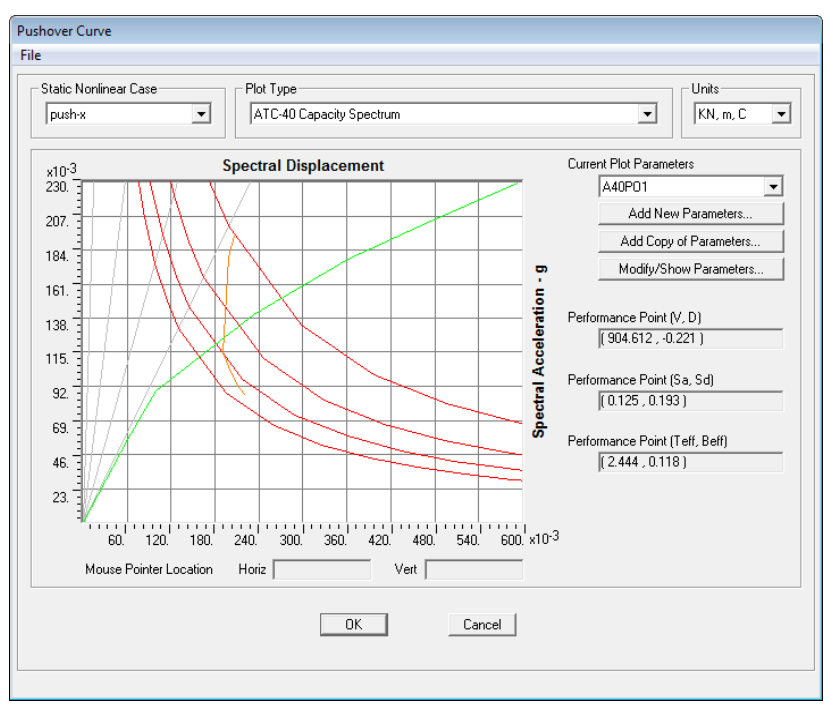

Fig -2: Capacity and demand curves for PUSH X load case

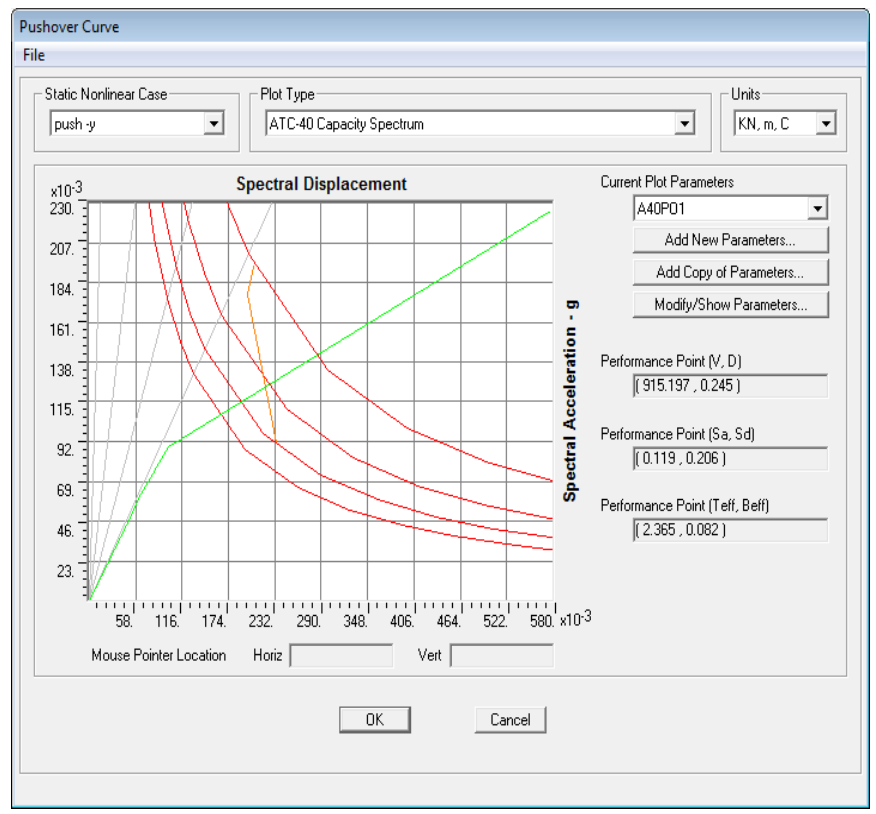

Fig -3: Capacity and demand curves for PUSH Y load case

\section{CONCLUSIONS}

- Building designed with IS 1893:2002 found to have a better performance under given earthquake.

- The design base shear of the building frame is found to be $720 \mathrm{KN}$ as per calculation. After performing the analysis the base shear at performance point is found to be $915 \mathrm{KN}$ which is greater than design base shear. Since at the performance point base shear is greater than the design base shear the building frame is safe under the earthquake loading.

\section{REFERENCES}

[1]. Konuralp Girgin and Kutlu Darılmaz.(December 2007) Seismic Response of Infilled Framed Buildings Using Pushover Analysis. Department of Civil Engineering, Istanbul Technical University, 34469, Maslak, Istanbul, Turkey VOLUME 54, NUMBER 5. 5 December 2007

[2]. Chopra A.K. and Goel R.K.(1999/02) "Capacity demand diagram methods for estimating seismic deformation of inelastic structures SDOF systems", PEER Report, Pacific Earthquake Engineering Research Centre, University of California

[3]. Peter Fajafar M.EERI (2000) "A non linear analysis method for Performance based seismic design", Earthquake spectra, vol.16,no.3,pp 573-592

[4]. Chopra A.K. and Goel R.K. (2001/03) "A Modal Pushover Analysis Procedure to Estimating Seismic Demands for Buildings: Theory and Preliminary Evaluation", PERR Report, Pacific Earthquake Engineering Research Centre, University of California

[5]. Dalal Sejal P., Vasanwala S.A., Desai A.K.(2011) "Performance based seismic design of structure: A review", International Journal Of Civil And Structural Engineering ,Volume 1, No 4 Mohammed S. Al-Ansari(2011), "Formulating building response to Earthquake loading", International Journal Of Civil And Structural Engineering Vol. 2, No 1.

[6]. IS:456:2000 Plain and Reinforced code of practice, IS: 875 Code of practice for design loads, IS:1893(Part-1):2002 Criteria for earth quake resistant design of structure, IS:13920:1993 Ductile detailing of RCC structure subjected to earth quake force.

[7]. Murthy C.V.R, Learning earthquake design

[8]. Agrawal, Shrikhande Mansih, earth quake resistant design of structures

[8]. Chopra A.K., Dynamics of structures- theory and applications to earthquake engineering 